Document downloaded from:

http://hdl.handle.net/10251/60270

This paper must be cited as:

Calatayud, V.; Cervero, J.; Calvo, E.; García Breijo, FJ.; Reig Armiñana, J.; Sanz, M. (2011). Responses of evergreen and deciduous Quercus species to enhanced ozone levels. Environmental Pollution. 159(1):55-63. doi:10.1016/j.envpol.2010.09.024.

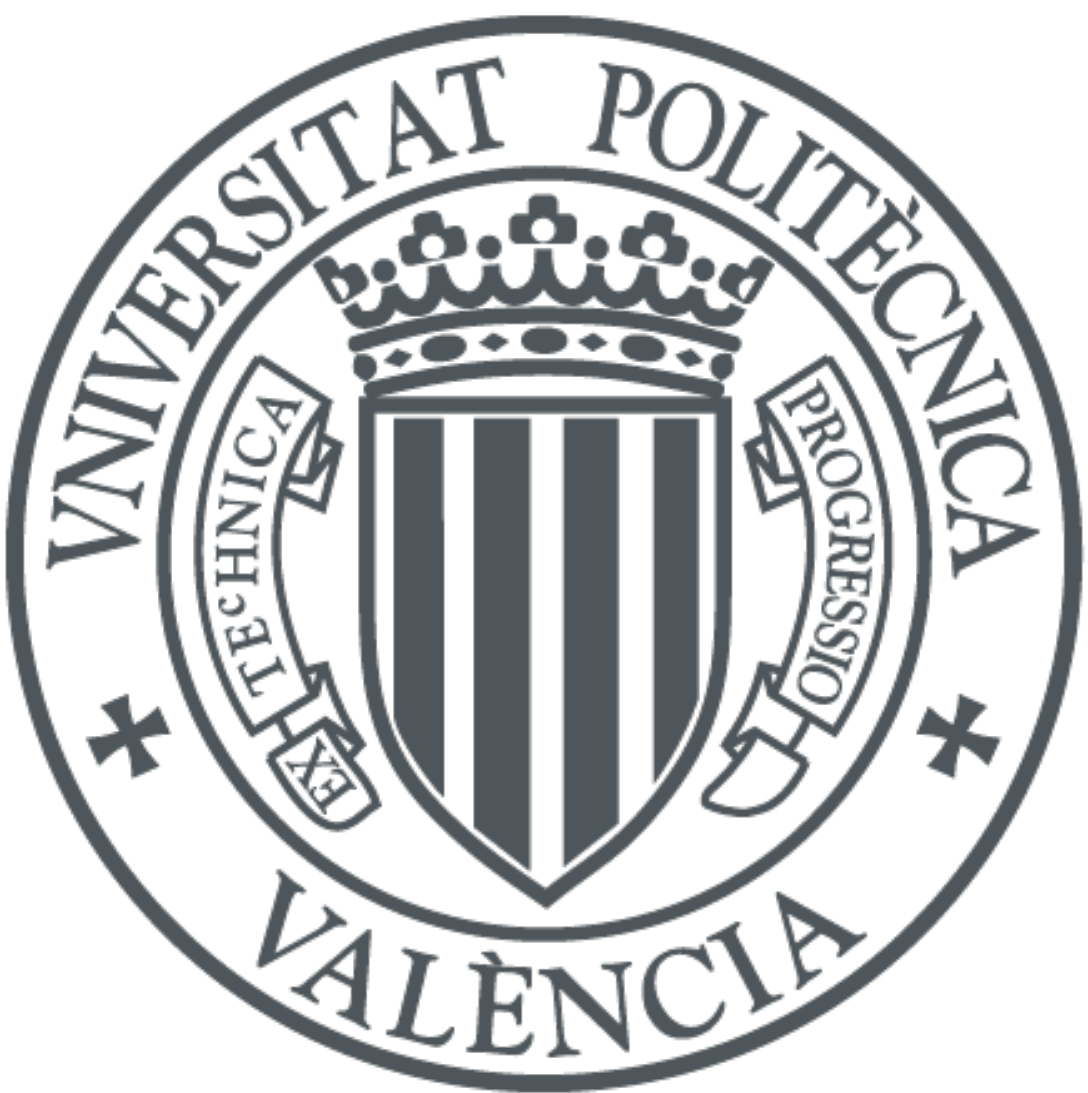

The final publication is available at

http://dx.doi.org/10.1016/j.envpol.2010.09.024

Copyright Elsevier

Additional Information 


\title{
Responses of evergreen and deciduous Quercus species to enhanced ozone levels
}

\author{
Vicent Calatayud ${ }^{\mathrm{a}, *}$, Júlia Cerveró $^{\mathrm{a}}$, Esperanza Calvo ${ }^{\mathrm{a}}$, Francisco-José García-Breijo ${ }^{\mathrm{b}, \mathrm{c}}$, \\ José Reig-Armiñana ${ }^{\mathrm{c}}$, María José Sanz ${ }^{\mathrm{a}}$ \\ a Instituto Universitario CEAM-UMH, Charles R. Darwin 14, Parc Tecnològic, 46980 Paterna, Valencia, Spain \\ b Laboratorio de Anatomía e Histología Vegetal "Julio Iranzo", Jardín Botánico, Universitat de València, c/Quart 80, 46008 Valencia, Spain \\ ${ }^{\mathrm{c}}$ Departamento de Ecosistemas Agroforestales, Escuela Técnica Superior del Medio Rural y Enología, Universidad Politécnica de Valencia, Avda. Blasco Ibáñez 21, \\ 46010 Valencia, Spain \\ Ozone tolerance overlapped with leaf traits in four Quercus species.
}

\section{A R T I C L E I N F O}

\section{Keywords:}

Ozone

Functional leaf traits

Stomatal conductance

Photosynthesis

Critical levels

Anatomy

\begin{abstract}
A B S T R A C T
Plants of one evergreen oak (Quercus ilex) and three deciduous oaks (Q. faginea, with small leaves; $Q$. pyrenaica and $Q$. robur, with large leaves) were exposed both to filtered air and to enhanced ozone levels in Open-Top Chambers. $Q$. faginea and $Q$. pyrenaica were studied for the first time. Based on visible injury, gas exchange, chlorophyll content and biomass responses, $Q$. pyrenaica was the most sensitive species, and Q. ilex was the most tolerant, followed by Q. faginea. Functional leaf traits of the species were related to differences in sensitivity, while accumulated ozone flux via stomata $\left(\mathrm{POD}_{1.6}\right)$ partly contributed to the observed differences. For risk assessment of Mediterranean vegetation, the diversity of responses detected in this study should be taken into account, applying appropriate critical levels.
\end{abstract}

\section{Introduction}

Ozone is generally recognized to be the most relevant pollutant for forests, affecting tree species in different ways: visible injury, reductions in biomass, changes in biomass partitioning, or a higher susceptibility to pathogen attack (Krupa et al., 2000). In its interaction with other pollutants and with climate change, it can also adversely affect important forest services (production, protection or regulatory services like water provision) (Bytnerowicz et al., 2007). Oaks are important trees in Northern Hemisphere forests. The genus Quercus encompasses both evergreen and deciduous species. In Spain, where Atlantic and Mediterranean vegetation

Abbreviations: $A$, net $\mathrm{CO}_{2}$ assimilation per unit area at a PPFD of $1000 \mu \mathrm{mol} \mathrm{m}{ }^{-2} \mathrm{~s}^{-1}$; AOT40, accumulated exposure over threshold $40 \mathrm{ppb} ; C_{\mathrm{i}}$ intercellular $\mathrm{CO}_{2}$ concentration; $F_{\mathrm{v}}: F_{\mathrm{m}}$, maximum quantum efficiency of photosystem II (PSII) primary photochemistry; $g_{\max }$, maximum stomatal conductance for water vapour; $g_{s}$, stomatal conductance to water vapour; LMA, leaf mass per area (=1/SLA); POD $_{1.6}$, Phytotoxic Ozone Dose over a threshold of $1.6 \mathrm{nmol} \mathrm{m}{ }^{-2} \mathrm{~s}^{-1}$ (formerly $\mathrm{AF}_{\mathrm{st}} 1.6$ or $\mathrm{CUO}>1.6$ ); PPFD, photosynthetic photon flux density; SLA Specific Leaf Area; $T_{\mathrm{r}}$, transpiration rate; WUE, Water Use Efficiency as the ratio $A / T_{\mathrm{r}}$ $C L e_{\mathrm{f}}$, Ozone Critical Level flux-based; CLe, Ozone Critical Level.

* Corresponding author.

E-mail addresses: calatayud_viclor@gva.es, vicent@ceam.es (V. Calatayud). converge, the most relevant species are $Q$. ilex (evergreen), and $Q$. faginea, Q. pyrenaica and Q. robur (deciduous) (López-González, 2001). Q. robur is a common oak in Europe, widely distributed in oceanic and humid areas, but absent from the Mediterranean Basin as it is drought-sensitive. The distribution of $Q$. pyrenaica is centred in western Mediterranean mountains, on relatively fresh sites. Q. faginea grows in similar habitats, but it has a more southern distribution and is relatively more drought tolerant. $Q$. ilex is widespread in the Mediterranean area; subsp. ballota, in particular, is very well adapted to drought stress. As adaptations to their different habitats, leaves of $Q$. robur and $Q$. pyrenaica are relatively large while those of $Q$. ilex subsp. ballota are the smallest and toughest; $Q$. faginea leaves are intermediate in size between the two.

Ozone effects on oaks have been studied in a limited number of North American (especially in Quercus rubra, e.g., EPA, 2006) and European species. As for European oaks, Q. petraea (Broadmeadow et al., 1999; Broadmeadow and Jackson, 2000; Karlsson et al., 2004), Q. robur (e.g. Broadmeadow et al., 1999; Broadmeadow and Jackson, 2000; Karlsson et al., 2004), Q. ilex (Inclán et al., 1999; Manes et al., 1998; Ribas et al., 2005a, 2005b) and Q. coccifera (Elvira et al., 2004) have been exposed previously to enhanced ozone levels. Such studies focussed on one or two oak species, sometimes comparing them with species of other genera. Of the four most common oak 
trees in the Iberian Peninsula, only two have been tested hitherto ( $Q$. robur and $Q$. ilex), and no information is currently available for $Q$. faginea and $Q$. pyrenaica. In the present 2-year study, we assess the ozone sensitivity of these four species by studying different types of responses: visible injury, and effects on photosynthesis and biomass. The hypothesis to be tested is that ozone sensitivity in these species is the result of the interaction between ozone uptake and species-specific leaf characteristics (e.g., leaf habit, SLA, thickness, stomatal density), which in the present case are strongly determined by the adaptations of these species to more or less dry habitats (Paoletti, 2006; Bussotti, 2008; Calatayud et al., 2010). Among these characters, Leaf Mass per Area (LMA), the inverse of Specific Leaf Area (SLA), has been used to distinguish between ozone-tolerant and ozone-sensitive species (Bussotti, 2008), and it has been suggested that data expressed on an LMA basis may contribute to a better understanding of the ozone effects (Cascio et al., 2010).

On the other hand, the results herein reported should contribute to the establishment of reliable critical levels (CLe) as risk-assessment tools for different types of Mediterranean species, on which information is clearly insufficient. The CLe established to protect vegetation in Europe has been based on the accumulated exposure over a Threshold of $40 \mathrm{ppb}$ during daylight hours (AOT40) (EU Directive, Official Journal of the European Union, 2008). More recently, a range of flux-based CLe have been proposed for different types of vegetation: the Phytotoxic Ozone Dose above the threshold of $\mathrm{Y} \mathrm{nmol} \mathrm{m} \mathrm{m}^{-2} \mathrm{~s}^{-1}$ (PODY) (Harmens et al., 2010), previously known as accumulated stomatal flux of ozone above the threshold of $\mathrm{Y}, \mathrm{AF}_{\mathrm{st}} \mathrm{Y}$ (UNECE, 2004). In the dose-response functions between growth and $\mathrm{AOT} 40$ or $\mathrm{POD}_{\mathrm{Y}}$ from which such CLe were derived - including a CLe for deciduous Quercus species (Karlsson et al., 2004) -, the threshold for PODY was $Y=1.6$ and a $5 \%$ growth reduction was regarded as relevant. However, in a very recent approach (Harmens et al., 2010), lower thresholds ( $\mathrm{Y}=0$ and $\mathrm{Y}=1$ ) and percentages of biomass reductions ( $2 \%$ or $4 \%$ ) have been proposed for Norway spruce, birch and beech, although not for Quercus. In the present paper, in order to facilitate comparability with previous studies (e.g., Karlsson et al., 2004), the discussion will be mainly based in $\mathrm{POD}_{1.6}$ and a $5 \%$ growth reduction will be considered. However, accumulated ozone stomatal fluxes will also be reported for $\mathrm{Y}=1$ and $=0$.

\section{Materials and methods}

\subsection{Plant material}

Two-year-old seedlings were obtained from Vivero Escuela Rio Guadarrama (Navalcarnero, Madrid). Plant material sources were: Sayazo, Salamanca (Quercus ilex subsp. ballota and Quercus pyrenaica); Alcarria, Serranía de Cuenca (Quercus faginea) and Galicia (Quercus robur). The $10 \mathrm{l}$ containers were filled with a mixture of $75 \%$ peat, $15 \%$ sand, and $10 \%$ vermiculite; the soil $\mathrm{pH}$ was close to 7.0 . A slow-release fertilizer was initially incorporated into the soil (Osmocote plus, $1 \mathrm{cc} \mathrm{l}^{-1}$, with NPK

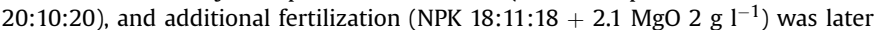
added regularly. Plants were irrigated twice a day using a droplet irrigation system. Nine plants were kept in filtered air, and 9 were ozone-exposed.

\subsection{Leaf trait and microscopy methods}

During July 2006, 3 mature leaves from each of the 9 Charcoal Filtered plants were collected $(n=27)$, and their Specific Leaf Area was calculated as SLA = Dry weight ( $\mathrm{mg}$ )/Leaf surface $\left(\mathrm{mm}^{2}\right)$. Leaf Mass per Area (LMA) is the inverse of SLA. Leaf dry weight was determined by oven-drying leaves at $60^{\circ} \mathrm{C}$ to stable weight. Leaf size was assessed by image analysis using Matrox Inspector 4.0 (Matrox Electronic Systems Ltd.). For anatomical traits, 5 cuttings or field observations per plant from 5 plants were evaluated under a light microscope. Leaves were embedded in LR-White medium-grade acrylic resin (London Resin Co.), and semi-thin sections (1.5 $\mu \mathrm{m})$ were prepared with a Sorvall MT 5000 ultramicrotome (Girald-Dupont, Willington, DE, USA) provided with a glass knife $\left(45^{\circ}\right)$ obtained from a special glass (Glass Strips Leica $6.4 \mathrm{~mm}$ ) in a knifemaker (Reichert-Jung, Wien, Austria). For stomatal traits, leaf trichomes were removed using adhesive tape. Leaves were washed with $2 \%$ sodium hypochlorite for $4 \mathrm{~h}$, then washed 4 times (20 min each time) in distilled water, and later stained in safranin-fast green for $25 \mathrm{~min}$. After several washings in alcohol $96 \%$, leaf fragments of $7 \times 7 \mathrm{~mm}$ were dehydrated in absolute ethanol, and mounted in a slide with xylene and Canada balsam. Cells and stomata were examined and counted on the leaf surface along diagonal transects. The stomatal index (I) was calculated as follows: $I=[S /(E+S)]^{*} 100$, where $S$ is the number of stomata per unit area, and $\mathrm{E}$ is the number of epidermal cells per same unit area $\left(0.0784 \mathrm{~mm}^{2}\right)$. Sections were observed and photographed with an Olympus Provis AX 70 brightfield microscope fitted with a Lumenera Infinity 2-3C digital CCD camera, and images were subsequently analyzed with Adobe Photoshop CS4 extended software.

\subsection{Open-top chambers and ozone exposures}

The experiment was conducted with six NCLAN Open-Top Chambers placed in Benifaió $\left(39^{\circ} 16^{\prime} 14.8^{\prime} \mathrm{N}, 00^{\circ} 26^{\prime} 59.6^{\prime} \mathrm{W}\right.$, at $30 \mathrm{~m}$ of altitude). Air quality inside and outside the chambers was continuously monitored at regular intervals with an ozone monitor (Dasibi 1008-AH, Environmental Corp.); these monitors were calibrated periodically. Plants were placed in six Open-Top Chambers (OTC), with two ozone treatments ( 3 chambers per treatment): Charcoal Filtered air (CF), and Non Filtered air plus $30 \mathrm{ppb}$ ozone $(\mathrm{NF}+30)$. Plants were fumigated $8 \mathrm{~h}$ a day, from 10:00 to 18:00 CET, during the whole week. Ozone was generated from pure oxygen using a high-voltage electrical discharge generator (Sir S.A.). In 2006, fumigation started on 25 April and ended on 19 September and in 2007, it started on 2 May and ended on 14 September. The AOT40 (accumulated exposure over a threshold of $40 \mathrm{ppb}$ ) was calculated according to the methods described by the EU Directive (Official Journal of the European Union, 2008), using mean hourly values from 8:00 CET to 20:00 CET Values of the different ozone metrics are provided in Table 1.

\subsection{Assessment of visible symptoms}

All plants ( 9 per species and ozone treatment) were examined every two days to record the first date of symptom onset in each individual plant. Complementarily, once a week, both the percentage of affected leaves per plant (LA), and the percentage of area affected for the symptomatic leaves (AA) were scored in each plant, using a 5\% step scale. To evaluate whole plant injury, a Plant Injury Index (PII) was calculated combining these two parameters: $\mathrm{PII}=(\mathrm{LA} * \mathrm{AA}) / 100$

\subsection{Gas exchange measurements}

Gas exchange measurements were taken with an infrared gas analyzer (IRGA) (LICOR-6400, Li-cor Inc., Lincoln, NE, USA), at constant $\mathrm{T}\left(25^{\circ} \mathrm{C}\right)$, PPFD $\left(1000 \mu \mathrm{mol} \mathrm{m}^{-2} \mathrm{~s}^{-1}\right)$, and reference $\mathrm{CO}_{2}$ concentration $\left(370 \mu \mathrm{mol} \mathrm{mol}^{-1}\right)$. In 2006 , gas exchange measurements were taken in May, June, August and September, and in 2007, in May and September. Nine plants per treatment were selected for these

\section{Table 1}

Mean ozone concentrations and meteorological data for different daily time windows, AOT40 and maximum hourly value measured, for the two years covered by this experiment (25/04/2006-19/09/2006 and 02/05/2007-14/09/2007). The $8 \mathrm{~h}$ window, from 10 to $18 \mathrm{~h}$ (CET), covered the $8 \mathrm{~h}$ in which plants in the $\mathrm{NF}+30$ treatment were exposed to increased ozone levels. $\mathrm{CF}=$ Charcoal Filtered Air; $\mathrm{NF}+30=$ Non Filtered Air +30 ppb ozone. AA $=$ Ambient air, it is not a treatment but refers to the ozone levels measured at the experimental site outside the OpenTop Chambers.

\begin{tabular}{llllll}
\hline & $\begin{array}{l}24 \text { h mean } \\
\text { value }\end{array}$ & $\begin{array}{l}12 \text { h mean } \\
{[8-20 \mathrm{CET}]}\end{array}$ & $\begin{array}{l}8 \mathrm{~h} \text { mean } \\
{[10-18 \mathrm{CET}]}\end{array}$ & $\begin{array}{l}\text { Maximum } \\
\text { hourly } \\
\text { value }\end{array}$ & $\begin{array}{l}\text { AOT40 } \\
\mathrm{ppb} \mathrm{h}\end{array}$ \\
\hline 2006 & & & & & \\
{$\left[\mathrm{O}_{3}\right] \mathrm{CF}(\mathrm{ppb})$} & 13.2 & 14.5 & 16.6 & 51.0 & 0 \\
{$\left[\mathrm{O}_{3}\right] \mathrm{NF}+30(\mathrm{ppb})$} & 36.4 & 55.2 & 65.4 & 112.3 & 33,405 \\
{$\left[\mathrm{O}_{3}\right] \mathrm{AA}$ air $(\mathrm{ppb})$} & 26.8 & 40.2 & 42.9 & 67.0 & 7356 \\
$\mathrm{Temperature}\left({ }^{\circ} \mathrm{C}\right)$ & 23.3 & 26.7 & 27.8 & 38.1 & \\
$\mathrm{HR}(\%)$ & 68.4 & 53.9 & 49.7 & 97.0 & \\
$\mathrm{VPD}(\mathrm{kPa})$ & 1.1 & 1.7 & 2.0 & 5.9 & \\
$\mathrm{PAR}$ & 542 & 1058 & 1332 & 2009 & \\
$\left(\mu \mathrm{mol} \mathrm{m}{ }^{-2} \mathrm{~s}^{-1}\right)$ & & & & & \\
2007 & & & & & \\
{$\left[\mathrm{O}_{3}\right] \mathrm{CF}(\mathrm{ppb})$} & 13.7 & 11.6 & 13.5 & 55.0 & 25.2 \\
{$\left[\mathrm{O}_{3}\right] \mathrm{NF}+30(\mathrm{ppb})$} & 37.5 & 57.9 & 67.7 & 102.0 & 33,138 \\
{$\left[\mathrm{O}_{3}\right] \mathrm{AA}$ air $(\mathrm{ppb})$} & 30.9 & 43.8 & 47.3 & 75.0 & 8941 \\
$\mathrm{Temperature}\left({ }^{\circ} \mathrm{C}\right)$ & 23.2 & 26.7 & 27.6 & 40.0 & \\
$\mathrm{HR}(\%)$ & 65.4 & 51.7 & 47.9 & 96.1 & \\
$\mathrm{VPD}(\mathrm{kPa})$ & 1.1 & 1.8 & 2.0 & 6.7 & \\
$\mathrm{PAR}$ & 555 & 1081 & 1357 & 2081 & \\
$\left(\mu \mathrm{mol} \mathrm{m}{ }^{-2} \mathrm{~s}^{-1}\right)$ & & & & & \\
\hline
\end{tabular}


measurements and one leaf per plant was measured. In order to minimize any environmental condition shifts affecting gas exchange, measurements were taken by alternating the different species and ozone treatments considered.

2.6. Ozone stomatal flux modelling, dose-response functions and critical level calculations

Modelling of stomatal conductance for each species was carried out by using the multiplicative model included in the EMEP $\mathrm{DO}_{3} \mathrm{SE}$ deposition module (UNECE, 2004). For deciduous oaks, the parameterization by Karlsson et al. (2004) was used, while for the evergreen oak, $Q$. ilex, a parameterization for this species included in the 2009 revision of the Mapping Manual (2004) was applied (Table 2). Meteorological data (from a meteorological tower placed at the experimental site) and hourly ozone concentrations covered from 1st April to 30th September. Sitespecific $g_{\max }$ values (Table 4 ) were used for each Quercus species. These $g_{\max }$ values were calculated by taking the 95th percentile of all the valid values of stomata conductance. As plants were well-watered, a constant value of 1.0 was assumed for the $f_{S w p}$. For holm oak, the existing phenological function has maximal values during winter but forces a $g_{s}$ decline in summer, in order to reproduce the drought-induced reduction in gas exchange experienced by Mediterranean vegetation during this period; as this restriction is not observed under the well-watered conditions of the present experiment, this function was assumed to have a constant value of 1.0 Exposure and flux calculations included charcoal filtered controls, and were expressed on a yearly basis following Karlsson et al. (2004). The hypothetical value of the total biomass at zero exposure was calculated as the $y$-axes intercept (using extrapolation of the linear regression of total biomass versus AOT40 or POD ${ }_{1.6}$ ), and the reductions in the total biomass for each species were calculated in relation to this hypothetical value. Dose-response functions for deciduous oak species were derived by linear regression analyses between $\mathrm{AOT}_{40}$ or $\mathrm{POD}_{1.6}$ indices and total biomass reduction. Ozone Critical level was calculated considering a $5 \%$ of biomass reduction. $\mathrm{POD}_{1.6}$ expressed on an $\mathrm{LMA}$ basis was calculated as: $\mathrm{POD}_{1.6} / \mathrm{LMA}$

\subsection{SPAD measurements}

Chlorophyll content was estimated non-destructively with a portable chlorophyll meter (SPAD-520, Minolta) in the same leaves used for gas exchange and fluorescence analysis. This instrument uses measurements of transmitted radiation in the red and near infrared wavelengths to provide numerical values related to leaf chlorophyll content. The average of 3 measurements was calculated for each leaf.

\subsection{Chlorophyll a fluorescence measurements}

Chlorophyll fluorescence measurements were taken at ambient temperature in the same leaves used for gas exchange analysis. Measurements were carried out with a portable fluorometer (PAM-200, Walz, Effeltrich, Germany). Leaves were dark-adapted for at least 30 min prior to the measurements. After dark adaptation, the minimal fluorescence $\left(F_{0}\right)$ was determined using the measuring light. Subsequent application of a saturating white light flash $\left(0.8 \mathrm{~s}\right.$ at $\left.8000 \mu \mathrm{mol} \mathrm{m}{ }^{-2} \mathrm{~s}^{-1}\right)$ raises fluorescence to its maximum value $\left(F_{\mathrm{m}}\right)$. This allows the determination of the $F_{\mathrm{v}}: F_{\mathrm{m}}$ parameter, maximum quantum efficiency of photosystem II (PSII) primary photochemistry, given by $F_{\mathrm{v}}: F_{\mathrm{m}}=\left(F_{\mathrm{m}}-F_{\mathrm{o}}\right): F_{\mathrm{m}}$

\subsection{Biomass, biomass partitioning and plant height}

Plant height was measured nine times, at the start of ozone exposure (25th April 2006) and then, regularly, but only the last data are presented (4th September 2007). At the end of the experiment (19th September 2007), above-ground (leaves and

Table 2

Parameterization used for modelling ozone stomatal flux in deciduous and evergreen oaks.

\begin{tabular}{llll}
\hline Parameter & Units & Deciduous oaks & Evergreen oaks \\
\hline$g_{\max }$ & mmol $\mathrm{H}_{2} \mathrm{O} \mathrm{m}^{-2}$ PLA & See Table 4 & See Table 4 \\
$f_{\min }$ & fraction & 0.13 & 0.02 \\
$\mathrm{SGS}$ & DOY & 91 & 1 \\
$\mathrm{EGS}$ & DOY & 273 & 365 \\
$\mathrm{f}_{\text {phen_a }}$ & fraction & 0.3 & - \\
$\mathrm{f}_{\text {phen_b }}$ & fraction & 0.3 & - \\
$\mathrm{f}_{\text {phen_c }}$ & days & 50 & - \\
$\mathrm{f}_{\text {phen_d }}$ & days & 50 & - \\
light $_{\mathrm{a}}$ & adim. & 0.006 & 0.012 \\
$T_{\min }$ & ${ }^{\circ} \mathrm{C}$ & -5 & 1 \\
$T_{\mathrm{opt}}$ & ${ }^{\circ} \mathrm{C}$ & 22 & 23 \\
$T_{\max }$ & ${ }^{\circ} \mathrm{C}$ & 35 & 39 \\
$\mathrm{VPD}_{\max }$ & $\mathrm{kPa}$ & 1.1 & 2.2 \\
$\mathrm{VPD}_{\min }$ & $\mathrm{kPa}$ & 3.1 & 4.0 \\
\hline
\end{tabular}

woody parts separately) and below-ground biomass (roots) were calculated separately after oven-drying at $60{ }^{\circ} \mathrm{C}$ to stable weight.

\subsection{Statistical analyses}

Depending on the type of data, for the two-level analyses, either the independent $t$-test or the Mann-Whitney $U$ test was applied. For more than two cases, one-way Analysis of Variance (ANOVA) followed by LSD or Tukey HDS tests, or Kruskal-Wallis $\mathrm{H}$ test followed by pairwise multiple comparisons were carried out. Time effects on the physiological measurements were tested with repeatedmeasures ANOVA with ozone treatments and species as between-subjects factors (Table 6), and applying lower bound epsilon test for within-subjects factor and interactions terms. In biomass assessment, a two-way ANOVA was applied. A probability level $<0.05$ was considered statistically significant. As plants were regularly moved within and among chambers in order to avoid positional effects, the statistic unit is consider to be the plant. Data were analyzed using SPSS 15.0 for Windows (SPSS Inc.).

\section{Results}

\subsection{Leaf traits of the species}

Of the four species considered, $Q$. ilex was characterized as having tough leaves, smaller in size and thicker than in the other species, and presenting the lowest SLA (surface/weight ratio) and highest LMA (Table 3). Supporting tissue (cells with lignified walls) was more abundant than in the other species, a subepidermis layer was present, and a very dense layer of trichomes covered the lower leaf surface. All these characters are related to sclerophyll adaptations, as expected from a typical evergreen Mediterranean species. $Q$. faginea, a deciduous species and, after $Q$. ilex, the second most drought tolerant of the species studied, also developed relatively small leaves, with values of SLA and leaf thickness which were intermediate between those of $Q$. ilex and those of the other two deciduous oaks. Lignified cell walls and trichomes were less abundant than in Q. ilex, but more numerous than in the other two deciduous oaks. The other two oak species $(Q$. pyrenaica and $Q$. robur) had the largest and the thinnest leaves on average, with no subepidermis layer, reduced supportive tissue, and with their surface less covered by trichomes. $Q$. robur was the only species with a single layer of palisade parenchyma cells (two layers in the other species).

Comparison of the different stomatal characteristics among species shows that none of the characters was ranked according to the leaf size or drought-tolerance capacity of the species. As expected, $Q$. ilex was among the species with the highest stomatal density and stomatal index; however, of the other three species, $Q$. pyrenaica had the closest values to $Q$. ilex, and not $Q$. faginea, as would also be expected.

\subsection{Stomatal ozone flux}

Under the well-watered conditions of the present experiment, the $g_{\max }$ of the different species and their accumulated ozone flux over different thresholds ( $\mathrm{POD}_{\mathrm{Y}}$ ) are provided in Table 4. According to the $\mathrm{POD}_{\mathrm{Y}}$ values, the species are ranked as follows: $Q$. ilex $>$ Q. pyrenaica $>Q$. faginea $>Q$. robur. The highest $\mathrm{POD}_{\mathrm{Y}}$ value in $Q$. ilex despite its lower $g_{\max }$ is related to the fact that, contrary to the deciduous oaks, $g_{\mathrm{s}}$ was not limited at the beginning and at the end of the April-September period ( $f_{\text {phen }}$ limitation), and this species shows different responses against VPD and T (Table 2). For Q. ilex, if the $\mathrm{POD}_{1.6}$ is calculated considering 12 months (leaves are present during the whole year), $\mathrm{POD}_{1.6}$ would be 4.3 and $58.8 \mathrm{mmol} \mathrm{m}^{-2}$ for the $\mathrm{CF}$ and $\mathrm{NF}+30$ treatments respectively. If the $\mathrm{POD}_{1.6}$ taken by each of the species is expressed on an LMA basis, however, the ranking changed: Q. pyrenaica $>Q$. robur $>Q$. faginea $>Q$. ilex. That is, along the experiment, $Q$. pyrenaica is the species that has been exposed to a higher dose of ozone per mass unit. 
Table 3

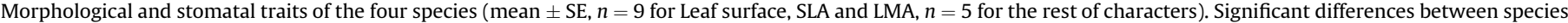

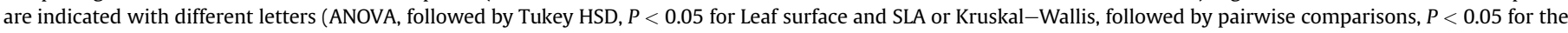
rest). Abundant $(++)$, moderate $(+)$, few $(-)$.

\begin{tabular}{|c|c|c|c|c|c|}
\hline & Units & Q. faginea & Q. ilex & Q. pyrenaica & Q. robur \\
\hline Leaf surface & $\mathrm{cm}^{2}$ & $6.5 \pm 0.3 \mathrm{a}$ & $5.7 \pm 0.4 \mathrm{a}$ & $28.8 \pm 1.7 \mathrm{c}$ & $18.1 \pm 0.9 \mathrm{~b}$ \\
\hline Specific Leaf Area (SLA) & $\mathrm{mm}^{2} \mathrm{mg}^{-1} \mathrm{DW}$ & $10.5 \pm 0.5 \mathrm{~b}$ & $6.7 \pm 0.6 \mathrm{a}$ & $13.3 \pm 0.6 c$ & $16.6 \pm 1.1 \mathrm{~d}$ \\
\hline Leaf Mass per Area (LMA) & $\mathrm{mg} \mathrm{cm} \mathrm{cm}^{-2} \mathrm{DW}$ & $9.7 \pm 0.4 \mathrm{~b}$ & $15.2 \pm 1.0 \mathrm{c}$ & $7.7 \pm 0.3 \mathrm{a}$ & $6.1 \pm 0.6 \mathrm{a}$ \\
\hline Subepidermis layer & & Absent & Present & Absent & Absent \\
\hline Palisade parenchima layer & $\mathrm{Nr}$ & 2 & 2 & 2 & 1 \\
\hline Trichomes & & + & ++ & + & - \\
\hline Cells with lignified walls & & + & ++ & - & - \\
\hline Leaf thickness & $\mu \mathrm{m}$ & $194.8 \pm 3.1 b$ & $227.5 \pm 3.3 c$ & $179.0 \pm 4.8 \mathrm{ab}$ & $155.7 \pm 2.1 \mathrm{a}$ \\
\hline Cuticle thickness & $\mu \mathrm{m}$ & $2.3 \pm 0.1 \mathrm{~ns}$ & $2.0 \pm 0.2 \mathrm{~ns}$ & $2.2 \pm 0.2 \mathrm{~ns}$ & $2.3 \pm 0.1 \mathrm{~ns}$ \\
\hline Upper epidermis & $\mu \mathrm{m}$ & $22.6 \pm 0.8 \mathrm{~ns}$ & $17.4 \pm 0.6 \mathrm{~ns}$ & $23.3 \pm 0.9 \mathrm{~ns}$ & $17.9 \pm 0.4 \mathrm{~ns}$ \\
\hline Lower epidermis & $\mu \mathrm{m}$ & $11.5 \pm 0.5 \mathrm{~ns}$ & $12.7 \pm 0.8 \mathrm{~ns}$ & $14.2 \pm 0.7 \mathrm{~ns}$ & $13.1 \pm 0.2 \mathrm{~ns}$ \\
\hline Palisade parenchima thickness & $\mu \mathrm{m}$ & $89.1 \pm 3.1 \mathrm{~ns}$ & $101.6 \pm 4.1 \mathrm{~ns}$ & $84.5 \pm 2.9 \mathrm{~ns}$ & $74.8 \pm 2.1 \mathrm{~ns}$ \\
\hline Spongy parenchyma thickness & $\mu \mathrm{m}$ & $68.2 \pm 1.7 \mathrm{a}$ & $86.9 \pm 1.6 \mathrm{~b}$ & $65.9 \pm 3.1 \mathrm{a}$ & $63.6 \pm 1.1 \mathrm{a}$ \\
\hline Stomatal density & stomata $\mathrm{mm}^{-2}$ & $200.6 \pm 6.8 \mathrm{~b}$ & $253.5 \pm 4.4 \mathrm{c}$ & $248.5 \pm 4.0 \mathrm{c}$ & $174.3 \pm 4.1 \mathrm{a}$ \\
\hline Stomatal index & $\%$ & $10.4 \pm 0.2 \mathrm{a}$ & $19.8 \pm 0.4 b$ & $18.8 \pm 0.3 b$ & $18.5 \pm 0.3 b$ \\
\hline Stomatal length & $\mu \mathrm{m}$ & $20.0 \pm 0.3 \mathrm{a}$ & $23.2 \pm 0.3 \mathrm{~b}$ & $19.5 \pm 0.3 \mathrm{a}$ & $23.6 \pm 0.4 \mathrm{~b}$ \\
\hline Stomatal width & $\mu \mathrm{m}$ & $19.0+0.33 c$ & $13.6+0.27 b$ & $10.7+0.15 a$ & $15.6+0.35 b$ \\
\hline
\end{tabular}

\subsection{Visible injury}

Q. ilex was asymptomatic during the two-year study period. In 2006 , all nine $Q$. pyrenaica plants developed visible injury, but only 5 did in 2007. For $Q$. faginea, and $Q$. robur, symptomatic plants were: 5 and 4 for the former, and 6 and 7 for the latter, in 2006 and 2007 respectively. In $Q$. pyrenaica, typical brown stipples were observed, while in $Q$. faginea and $Q$. robur, symptoms where less characteristic, consisting of more aspecific faint yellow areas (for photos, see Sanz and Calatayud, accessed May 2010). The onset of visible injury for $Q$. pyrenaica was in May, at much lower AOT40 and $\mathrm{POD}_{Y}$ values than in the other two symptomatic species (Table 5). For $Q$. robur and $Q$. faginea, visible injury could only be observed towards the end of the growing season in both years. Complementarily, the evolution of the Plant Injury Index was consistent with the previous results, supporting $Q$. ilex as the most tolerant species and Q. pyrenaica as the most sensitive one (Fig. 1). A reduction in the symptoms during the second year was also observed.

\subsection{Gas exchange, chlorophyll content (SPAD) and chlorophyll fluorescence}

Independently of the ozone treatment, the species were significantly different for most of the gas exchange and chlorophyll parameters considered, and showed differences in the variation along time (Table 6 ). For $\mathrm{CO}_{2}$ assimilation $(A)$, there is a significant interaction of ozone $\times$ species, indicating that ozone effects on $A$ differed among species. $Q$. pyrenaica and $Q$. robur were the species most affected by ozone, $Q$. ilex was the most tolerant (significant changes not observed), while $Q$. faginea was intermediate. In 2006, ozone reduced $A$ in all species $(-64 \%$ in
Q. pyrenaica, $-38 \%$ in $Q$. robur and $-33 \%$ in $Q$. faginea) except $Q$. ilex. Stomatal conductance $\left(g_{s}\right)$ and $A / g_{s}$ ratio were significantly reduced in $Q$. pyrenaica $\left(-26 \%,-52 \%\right.$ and $-51 \%$ respectively). $C_{\mathrm{i}}$ increased significantly in Q. pyrenaica (15\%) and Q. faginea (6\%), and chlorophyll content (SPAD) was reduced significantly in $Q$. pyrenaica (-25\%). In 2007, Q. pyrenaica and Q. robur experienced significant reductions in $A(-77 \%$ and $-25 \%), g_{s}(-64 \%$ and $-42 \%)$, and $A / g_{\mathrm{s}}$ ratio (24\% and $25 \%$ ) while $C_{\mathrm{i}}$ increased (21\% and $24 \%$ ). A decline in $F_{\mathrm{v}}: F_{\mathrm{m}}$ was observed in September 2007 in Q. pyrenaica $(-16 \%)$ and $Q$. robur $(-16 \%)$, although it was not significant. The type of approach used in this study, i.e., measuring the same (marked) leaves throughout the year, is useful for comparative purposes but may overestimate whole plant effects, as possible compensatory responses of younger leaves were not taken into account (Fig. 2).

\subsection{Biomass, biomass partitioning and plant height}

Independently of the ozone treatment, the species differed significantly in biomass production and plant height at the end of the experiment (Table 7). Plant height values at the end of the experiment did not differ significantly between the two treatments at any of the nine measuring times (only values of the last measuring time are reported in Table 6). Nor did the enhanced ozone levels significantly change the above-ground biomass. Root dry weight showed a tendency towards reduction in fumigated Q. pyrenaica plants $(-45 \%, P<0.1)$, and biomass partitioning was significantly altered in this species: reduction in root growth was stronger than reduction in above-ground biomass (13\%); thus, above-ground biomass/below-ground biomass ratio increased significantly in this species (50\%).

Table 4

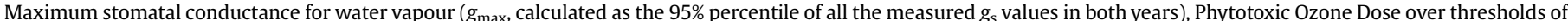
0,1 and $1.6 \mathrm{nmol} \mathrm{m}^{-2} \mathrm{~s}^{-1}$, and $\mathrm{POD}_{1.6}$ expressed on an LMA basis (means of two years). $g_{\mathrm{LDM}}=$ grams of leaf dry matter.

\begin{tabular}{|c|c|c|c|c|c|c|c|c|}
\hline & \multirow{2}{*}{$\begin{array}{l}g_{\max } \\
\left(\mathrm{mmol} \mathrm{H}_{2} \mathrm{O} \mathrm{m}^{-2} \mathrm{~s}^{-1}\right)\end{array}$} & \multicolumn{2}{|c|}{$\mathrm{POD}_{0}\left(\mathrm{mmol} \mathrm{m}^{-2}\right)$} & \multicolumn{2}{|c|}{$\mathrm{POD}_{1}\left(\mathrm{mmol} \mathrm{m}^{-2}\right)$} & \multicolumn{2}{|c|}{$\mathrm{POD}_{1.6}\left(\mathrm{mmol} \mathrm{m}^{-2}\right)$} & \multirow{2}{*}{$\frac{\text { POD }_{1.6}-\text { LMA basis }\left(\mathrm{mmol} \mathrm{g}_{\mathrm{LDM}^{-1}}\right)}{\mathrm{NF}+30}$} \\
\hline & & $N F+30$ & $\mathrm{CF}$ & $\mathrm{NF}+30$ & $\mathrm{CF}$ & $N F+30$ & $\mathrm{CF}$ & \\
\hline Q. faginea & 424.4 & 47.0 & 12.2 & 38.6 & 5.1 & 34.0 & 2.8 & 0.35 \\
\hline Q. ilex & 317 & 58.1 & 15.4 & 49.6 & 7.7 & 44.9 & 4.5 & 0.30 \\
\hline Q. pyrenaica & 469.9 & 51.1 & 13.3 & 42.6 & 6.0 & 38.1 & 3.5 & 0.49 \\
\hline Q. robur & 357.2 & 40.6 & 10.5 & 32.3 & 3.8 & 27.9 & 1.9 & 0.46 \\
\hline
\end{tabular}


Table 5

Symptom onset related to ozone exposure (AOT40 and $\mathrm{POD}_{\mathrm{Y}}$ ) for the four species.

\begin{tabular}{|c|c|c|c|c|c|c|c|c|}
\hline & \multicolumn{2}{|c|}{ AOT40 (ppb h) } & \multicolumn{2}{|c|}{$\begin{array}{l}\mathrm{POD}_{0} \\
\left(\mathrm{mmol} \mathrm{m}^{-2}\right)\end{array}$} & \multicolumn{2}{|c|}{$\begin{array}{l}\mathrm{POD}_{1} \\
\left(\mathrm{mmol} \mathrm{m}^{-2}\right)\end{array}$} & \multicolumn{2}{|c|}{$\begin{array}{l}\mathrm{POD}_{1.6} \\
\left(\mathrm{mmol} \mathrm{m}^{-2}\right)\end{array}$} \\
\hline & 2006 & 2007 & 2006 & 2007 & 2006 & 2007 & 2006 & 2007 \\
\hline Q. faginea & 28,223 & 26,181 & 36.38 & 34.58 & 30.83 & 29.17 & 27.74 & 26.16 \\
\hline Q. ilex & - & - & - & - & - & - & - & - \\
\hline Q. pyrenaica & 2883 & 3720 & 3.86 & 4.49 & 3.37 & 3.72 & 3.09 & 3.28 \\
\hline Q. robur & 26,181 & 23,367 & 28.74 & 29.24 & 23.99 & 24.05 & 21.40 & 21.22 \\
\hline
\end{tabular}

\subsection{Dose-response functions and critical levels}

When the reductions in total biomass vs. AOT40 and $\mathrm{POD}_{1.6}$ are represented (Fig. 3), the highest biomass reductions occurred in $Q$. pyrenaica, which was the deciduous species experiencing the highest accumulated ozone flux. Considering the exposure or doseresponse functions (Fig. 3 ) of the three deciduous species together, an AOT40 of about $18 \mathrm{ppm} \mathrm{h}$ and a $\mathrm{POD}_{1.6}$ of about $16 \mathrm{mmol} \mathrm{m}^{-2}$ would account for a $5 \%$ reduction in total biomass for the deciduous oak species. The only evergreen, $Q$. ilex, was by far the most tolerant species as it showed the lowest biomass reductions despite being exposed to the highest accumulated ozone flux of the four species: a reduction of $5 \%$ was associated with AOT40 values of $46 \mathrm{ppm} \mathrm{h}$ and POD $_{1.6}$ values of $53 \mathrm{mmol} \mathrm{m}^{-2}$ (or of $72 \mathrm{mmol} \mathrm{m}^{-2}$ if 12 months instead of 6 months are considered).

\section{Discussion}

The present study shows that realistic levels of ozone-induced leaf-level and plant-level responses were species-specific. Visible injury strongly varied among species, with $Q$. pyrenaica and $Q$. ilex being the most and least affected species respectively. Leaf injury also varied between years; it was lower in the second year, probably due to a better acclimatising to plot conditions (Bussotti et al., 2007). Visible injury onset for each species occurred at relatively similar AOT40 values in both years (less than $3000 \mathrm{ppb} h$ of difference, up to $23 \%$ deviation between years), but agreement was better for $\mathrm{POD}_{\mathrm{Y}}$ values (only up to $14 \%$ deviation, and practically identical values for $Q$. robur). Therefore, on the basis of these results, the uncertainty can be reduced if the threshold for the onset of visible foliar injury is based on stomatal flux rather than exposure (AOT40). Gerosa et al. (2008) obtained similar conclusions for Fagus sylvatica, outlining the higher potential of the fluxbased approach, as it takes into account environmental, biological and physiological factors affecting plant response which are not considered in an exposure-based approach (Karlsson et al., 2004). Physiological responses were basically consistent with the above results. At least in one of the two years (at the end of the growing season), $\mathrm{CO}_{2}$ assimilation $(A)$ was significantly reduced and intercellular $\mathrm{CO}_{2}$ concentrations $\left(C_{\mathrm{i}}\right)$ increased in all species except Q. ilex. In Q. pyrenaica (2006 and 2007) and Quercus robur (2007),

Table 6

$P$ values for main effects in repeated-measures ANOVA. Within-subjects factor (Time) effect and interactions were tested by lower bound epsilon.

\begin{tabular}{lllllll}
\hline & $A$ & $C_{\mathrm{i}}$ & $g_{\mathrm{s}}$ & $A / g_{\mathrm{s}}$ & $\mathrm{SPAD}$ & $F_{\mathrm{v}}: F_{\mathrm{m}}$ \\
\hline Time & 0.076 & $<0.001$ & $<0.001$ & $<0.001$ & 0.002 & $<0.001$ \\
Time $\times \mathrm{O}_{3}$ & 0.281 & 0.109 & 0.308 & 0.113 & 0.564 & 0.104 \\
Time $\times$ species & 0.408 & 0.113 & 0.185 & 0.080 & 0.367 & 0.020 \\
Time $\times \mathrm{O}_{3} \times$ species & 0.564 & 0.323 & 0.945 & 0.460 & 0.346 & 0.236 \\
$\mathrm{O}_{3}$ & $<0.001$ & 0.017 & 0.026 & 0.049 & 0.032 & 0.166 \\
Species & 0.038 & $<0.001$ & 0.054 & 0.001 & $<0.001$ & 0.037 \\
$\mathrm{O}_{3} \times$ species & 0.044 & 0.330 & 0.849 & 0.350 & 0.124 & 0.491 \\
\hline
\end{tabular}

stomatal conductance $\left(g_{\mathrm{s}}\right)$ and the ratio between $A / g_{\mathrm{s}}$ were also impaired. Similar physiological changes have been reported e.g., in maple species and in Pistacia and Viburnum shrubs (Calatayud et al., 2007, 2010). As these authors pointed out, the observed reductions of $\mathrm{CO}_{2}$ assimilation are associated with an increase in $C_{\mathrm{i}}$ and a reduction in WUE (or the related $A / g_{s}$ ), which suggest that Rubisco-related limitations may contribute to this decline in $\mathrm{CO}_{2}$ assimilation (e.g., Reichenauer and Bolhàr-Nordenkampf, 1999; Mikkelsen, 1995). The $A / g_{s}$ ratio (Fredericksen et al., 1996; Wei et al., 2004a, 2004b; Bussotti et al., 2007), or the related carbon gain $/ \mathrm{O}_{3}$ uptake ratio, have been suggested to be linked to the detoxification capacity and ozone tolerance of the plants. Higher values of this index would ensure a good balance between the feeding of the metabolic detoxification processes and the ozone uptake, as products of the photosynthetic reactions $\left(\mathrm{NADPH}^{+}\right.$or soluble carbohydrate) are involved in antioxidant regeneration and maintenance of the ascorbate pool (Matyssek et al., 2007). Bussotti et al. (2007) suggest a link between the reductions of this ratio observed towards the end of summer and the onset of visible injury. Consistently, in the present experiment, a decline in the $\mathrm{A} / \mathrm{g}_{\mathrm{s}}$ ratio in $Q$. pyrenaica and $Q$. robur towards the end of the summer may also be related with the rise (Q. pyrenaica) or onset ( $Q$. robur) of visible symptoms in this period. On the other hand, the decline in chlorophyll content in Q. pyrenaica (2006, significant) and in Q. robur (not significant) is also in line with previous observations, suggesting that, under enhanced ozone levels, some deciduous Quercus are particularly prone to experience chlorophyll degradation (compare with other genera, e.g., in Broadmeadow and Jackson, 2000, and Bussotti et al., 2007). Gas exchange results also underline the relative high tolerance of $Q$. ilex to enhanced ozone levels, as a decline in $\mathrm{CO}_{2}$ assimilation is one of the first responses in ozone-fumigated plants (Reich, 1987), not necessarily related to symptom development (Bussotti et al., 2007).

In the case of the present study, there is consistency in the fact that $Q$. pyrenaica, the species showing the earliest and most severe symptoms, and the strongest effects on photosynthesis, was also the one showing the highest biomass reductions. However, effects at leaf-level, and especially visible injury, are frequently uncoupled with growth or biomass reductions: the latter effects can be limited if, for example, leaves become affected toward the end of the growing season, when growth has already stopped or is reduced (Novak et al., 2007), or by compensatory responses of younger or non-affected leaves. Also in Quercus pyrenaica, root biomass (and the ratio between above-ground and root biomass) was more importantly affected than above-ground biomass. Ozone effects on roots and/or on the above-mentioned ratio have been reported as a consequence of reduction in $\mathrm{CO}_{2}$ assimilation but also of photoassimilate allocation from source tissues (leaves) to sink tissues (roots) (Andersen, 2003). Under natural conditions, root reduction and changes in biomass partitioning in tree species may reduce resistance to windthrow (Broadmeadow and Jackson, 2000). However, it is advised that extrapolation of OTC results to field conditions and mature trees are subject to important uncertainties. In the other three species, biomass effects were lower.

By integrating all the different response indicators studied, the ranking from more to less ozone-sensitive oaks is as follows: $Q$. pyrenaica $>Q$. robur $>Q$. faginea $>Q$. ilex. The most tolerant species was $Q$. ilex, followed by $Q$. faginea, the deciduous species with the smallest leaves, while $Q$. pyrenaica, with the largest leaves, was the most sensitive. This ranking is not fully consistent with the $\mathrm{POD}_{\mathrm{Y}}$ values calculated for the different species, i.e., differences in accumulated ozone flux among species alone do not explain the different responses observed. However, when the $\mathrm{POD}_{1.6}$ is expressed on an LMA basis (i.e., the ozone dose is 

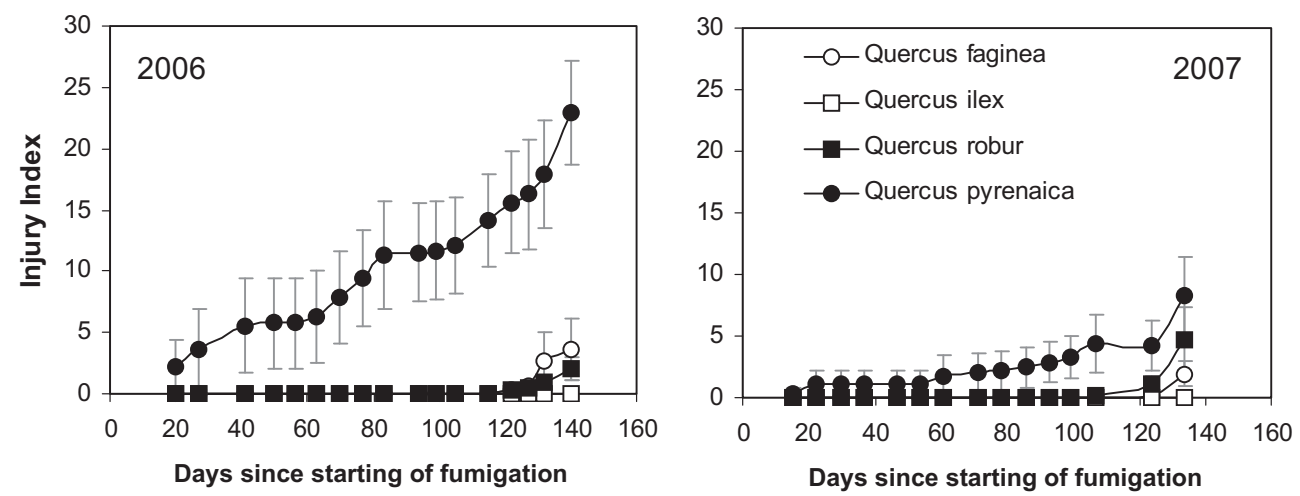

Fig. 1. Evolution of Plant Injury Index in 2006 and 2007 in the NF+30 treatment (mean, $n=9$ ).

expressed per mass unit), there is good agreement between the resulting ranking and the one reported above. These results suggest that functional traits such as LMA could be considered in combination with stomatal ozone flux to better define the potential ozone risk for plants with different types of leaves and ecological requirements. In fact, LMA index has previously been used to distinguish between ozone-sensitive and ozone-tolerant species (Bussotti, 2008). High LMA reflect a high density in mesophyll tissues or thick leaves. This index is also considered an index of sclerophylly: sclerophylly begins at $7.5 \mathrm{mg} \mathrm{cm}^{-2}$ (Bussotti,

$\square$ Quercus faginea

$\square$ Quercus ilex

Q Quercus pyrenaica

Q Quercus robur

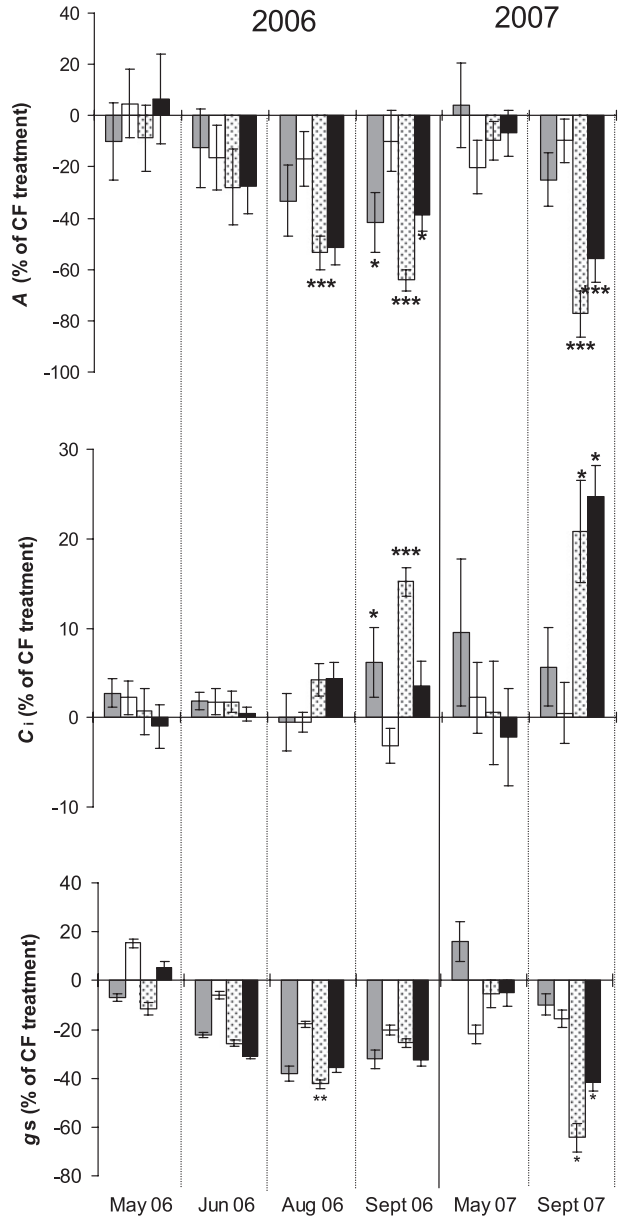

Date

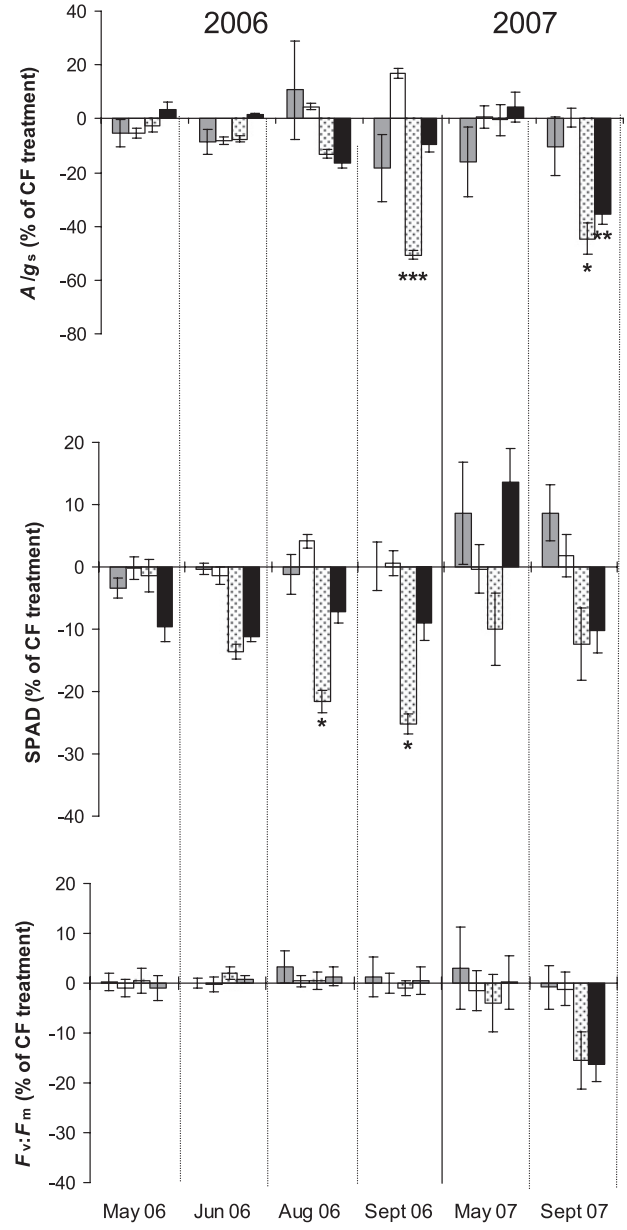

Date

Fig. 2. Changes in gas exchange and chlorophyll parameters at the different measuring times. Significant differences of $\mathrm{NF}+30$ treatment with respect to control treatment (CF) are indicated with: ${ }^{*} P<0.05 ;{ }^{* *} P<0.01 ;{ }^{* * *} P<0.001(n=9)$. 
Table 7

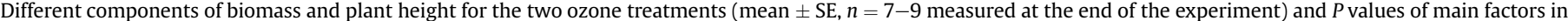
two-way ANOVA. Significant differences between treatments are indicated with an asterisk $\left(t\right.$-test, $\left.{ }^{*} P<0.05\right)$.

\begin{tabular}{|c|c|c|c|c|c|c|}
\hline & & Total biomass (g DW) & Above-ground biomass (g DW) & Roots (g DW) & Above-ground biomass/Roots & Plant height $(\mathrm{cm})$ \\
\hline \multirow[t]{2}{*}{ Q. faginea } & $\mathrm{CF}$ & $321.4 \pm 40.5$ & $135.3 \pm 12.2$ & $186.2 \pm 31.4$ & $0.9 \pm 0.1$ & $125.5 \pm 11.9$ \\
\hline & $\mathrm{NF}+30$ & $286.6 \pm 47.6 \mathrm{~ns}$ & $138.0 \pm 16.0 \mathrm{~ns}$ & $148.6 \pm 37.5 \mathrm{~ns}$ & $1.3 \pm 0.3 \mathrm{~ns}$ & $109.0 \pm 11.8 \mathrm{~ns}$ \\
\hline \multirow[t]{2}{*}{ Q. ilex } & $\mathrm{CF}$ & $242.2 \pm 28.0$ & $142.3 \pm 16.0$ & $100.0 \pm 14.0$ & $1.6 \pm 0.2$ & $118.4 \pm 9.1$ \\
\hline & $\mathrm{NF}+30$ & $224.2 \pm 38.4 \mathrm{~ns}$ & $135.8 \pm 20.8 \mathrm{~ns}$ & $88.4 \pm 18.5 \mathrm{~ns}$ & $2.2 \pm 0.5 \mathrm{~ns}$ & $99.9 \pm 12.5 \mathrm{~ns}$ \\
\hline \multirow[t]{2}{*}{ Q. pyrenaica } & $\mathrm{CF}$ & $192.0 \pm 48.9$ & $70.4 \pm 19.2$ & $121.6 \pm 30.0$ & $0.5 \pm 0.0$ & $57.9 \pm 7.4$ \\
\hline & $N F+30$ & $128.9 \pm 44.2 \mathrm{~ns}$ & $61.4 \pm 21.6 \mathrm{~ns}$ & $67.4 \pm 23.0 \mathrm{~ns}$ & $1.0 \pm 0.2 *$ & $67.0 \pm 13.4 \mathrm{~ns}$ \\
\hline \multirow[t]{2}{*}{ Q. robur } & $\mathrm{CF}$ & $474.6 \pm 32.0$ & $224.7 \pm 14.8$ & $249.9 \pm 20.6$ & $0.9 \pm 0.1$ & $140.5 \pm 9.7$ \\
\hline & $\mathrm{NF}+30$ & $425.8 \pm 28.1 \mathrm{~ns}$ & $194.6 \pm 11.8 \mathrm{~ns}$ & $231.2 \pm 19.9 \mathrm{~ns}$ & $0.9 \pm 0.1 \mathrm{~ns}$ & $128.9 \pm 6.6 \mathrm{~ns}$ \\
\hline \multicolumn{7}{|c|}{$P$ values of main factors } \\
\hline \multicolumn{2}{|c|}{$\mathrm{O}_{3}$} & 0.156 & 0.433 & 0.091 & 0.026 & 0.245 \\
\hline \multicolumn{2}{|l|}{ Species } & $<0.001$ & $<0.001$ & $<0.001$ & $<0.001$ & $<0.001$ \\
\hline \multicolumn{2}{|l|}{$\mathrm{O}_{3} \times$ species } & 0.956 & 0.807 & 0.829 & 0.490 & 0.509 \\
\hline
\end{tabular}

2008), and LMA in Q. ilex is 15.2 , and in Q. faginea, $9.7 \mathrm{mg} \mathrm{cm}^{-2}$. As observed in these two species, sclerophyllous adaptations include the development of cells with thick walls and more supportive tissue that can affect gas diffusion inside the leaves. Thick leaves are considered to be more ozone-tolerant than thinner leaves (Pääkkönen et al., 1995a, 1997; Bennet et al., 1992; Lyons et al., 2000; Karlsson et al., 2007), in part because of differences in the gas-phase diffusion pathways (Chappelka and Samuelson, 1998). The presence of cells with thick walls strongly influences the length of the diffusion pathway for ozone and modifies the interaction with oxidative constituents of the apoplast; the density of the cell wall (i.e., degree of cross-linking, suberification or lignification) would also be expected to influence the tortuosity of the diffusion pathways for ozone (reviewed in Lyons et al., 2000). Furthermore, in the case of $Q$. ilex, the dense trichoma layer present in the lower leaf surface increases boundary layer resistance, and eventually may increase the surface of reaction with ozone, contributing to its deplection. In addition to these processes, leaves with higher LMA values (lower SLA values) have been correlated with higher antioxidant capacity levels (Matyssek et al., 2007), and a high tissue density is considered to be able to better feed detoxification processes (Bussotti, 2008). Finally, plants growing in the Mediterranean area are adapted to different oxidative stress factors (e.g., high temperature, strong sun-light, drought) that can make them more tolerant to ozone stress, as molecular responses to all these stresses may be convergent (Paoletti, 2006; Bussotti, 2008; Calatayud et al., 2010). Overall, the results of the present study are consistent with previous studies comparing related Mediterranean evergreen and deciduous species, which showed a much higher tolerance in evergreen species (Calatayud et al., 2010), and also with other studies comparing different deciduous species among them: plants with smaller, more coriaceous and thicker leaves, withstood ozone stress better (Calatayud et al., 2007; Bussotti et al., 2007; Bussotti, 2008). The higher sensitivity of $Q$. pyrenaica is related to its large leaves, relatively thin, and high $g_{\max }$ and $\mathrm{POD}_{\mathrm{Y}}$ values. In this experiment, $Q$. robur is intermediate, and it is considered more tolerant than Fagus sylvatica or Betula pendula (Karlsson et al., 2004, 2007; Bussotti et al., 2007). In summary, the hypothesis that ozone sensitivity would be species-specific and related to leaf traits (Bussotti et al., 2008; Calatayud et al., 2010) was basically confirmed. Moreover, a partial overlapping of ozone resistance with drought tolerance of the species (Nali et al., 2004) was also confirmed. This overlapping was expected, as in the studied species the above-mentioned anatomical features favouring ozone tolerance (e.g., sclerophylly) are developed as adaptations to dry habitats.

Although there are differences in the stomatal characters among species, there is not an evident correlation with ozone sensitivity. For example, both the most tolerant $(Q$. ilex) and the most sensitive ( $Q$. pyrenaica) species did not show significant differences in stomatal index and stomatal density. In Betula spp., it has been suggested that leaves with a higher stomatal density may be more resistant to ozone (Pääkkönen et al., 1995a, 1997, 1993; Lyons et al., 2000), probably because an even distribution of ozone uptake may facilitate a greater interception and
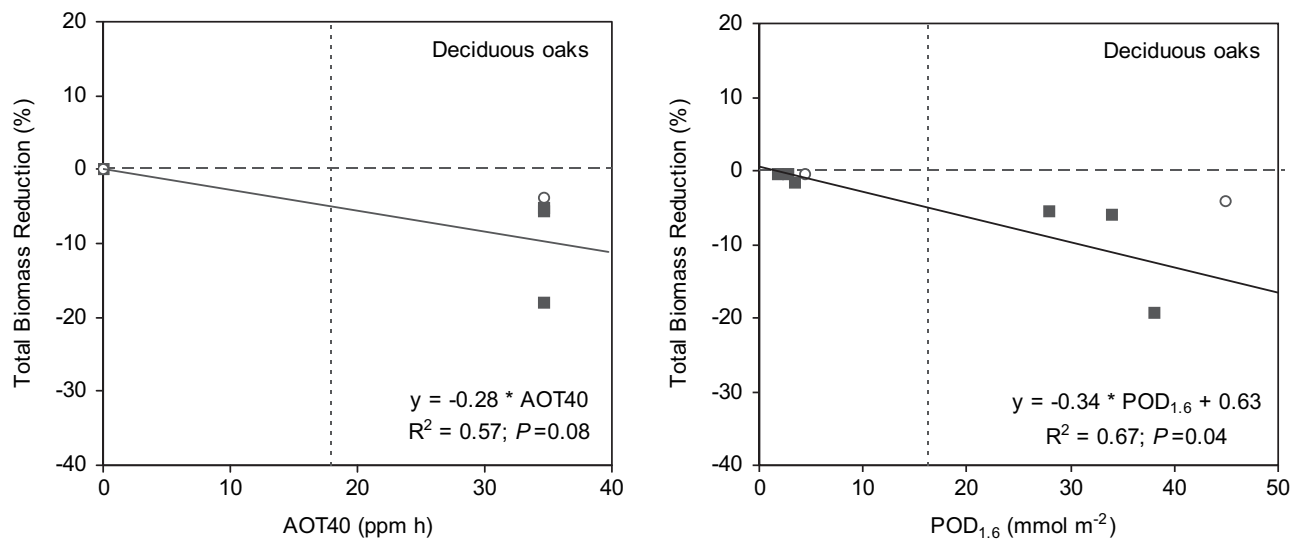

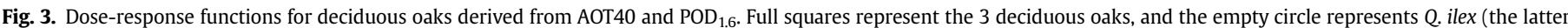

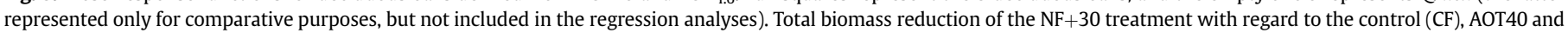
$\mathrm{POD}_{1.6}$ are calculated on a yearly basis. Vertical dashed line marks the ozone level for a $5 \%$ reduction in growth. 
detoxification of the pollutant (Pääkkönen et al., 1995b; Lyons et al., 2000). In the present study, however, very different types of leaves have been compared, and the relevance of stomatal characters in relation to ozone sensitivity seems to be secondary with regard to other morphological features. On the other hand, stomatal density may have a high variability inside a leaf and a crown (Paoletti and Gellini, 1993).

Under Mediterranean field conditions, the differences in ozone responses observed between the species under the well-watered conditions of this experiment could be modulated by their type of interaction with drought. Evergreen species have developed a conservative water-use strategy, showing a high stomatal sensitivity to drought (Mediavilla and Escudero, 2003). In summer, Q. ilex strongly reduces stomatal conductance, thereby limiting ozone uptake (Gerosa et al., 2005; Manes et al., 2007); this would further contribute to preventing ozone effects in this species under field conditions. In contrast, deciduous species such as $Q$. faginea, and more particularly $Q$. pyrenaica, show a non-conservative strategy, maintaining stomatal conductances relatively high even in summer; this is probably possible by developing deep roots that may have access to tap soil water reserves (Gallego et al., 1994; Mediavilla and Escudero, 2003). Q. robur is distributed in areas with higher water availability. Therefore, it is expected that the species-specific differences in ozone responses observed under well-watered conditions may become even more marked under natural conditions if the summer drought component is also included. However, ozone interactions with drought can be complex. The moment at which ozone episodes occur can be relevant. In Aleppo pine, when a drought period was applied after ozone exposure, the combined effects of both stresses decreased the capacity of plant recovery after rewatering (Alonso et al., 2001). Paoletti (2005) observed that ozone exposure impaired stomatal responses in evergreen species, which could make plants exposed to this pollutant more vulnerable to subsequent drought episodes. Clearly, more research combining ozone with drought is still needed in order to better understand the behaviour and potential risks due to this pollutant under natural conditions in the Mediterranean area.

Finally, and assuming the limitations of being based on a single experiment, dose-response functions have been applied for comparative purposes with previous studies with Quercus (Karlsson et al., 2004). Considering the three deciduous oak species together and the parameterization applied in this study, an AOT40 of $18 \mathrm{ppm} \mathrm{h}$ and a POD $_{1.6}$ of about $16 \mathrm{mmol} \mathrm{m}^{-2}$ would account for a $5 \%$ biomass loss. This AOT40 value is identical to that proposed by Karlsson et al. (2004) for deciduous oaks; however, the $\mathrm{POD}_{1.6}$ value is above the $C L e_{\mathrm{f}}$ of $12 \mathrm{mmol} \mathrm{m}^{-2}$ proposed for this type of oak by the same authors. This is not surprising as in the present experiment relatively tolerant species such as Q. faginea have been included, and there can be considerable variation between experiments. For holm oak, the limited results of this experiment suggest that AOT40 and POD $_{1.6}$ values suitable for preventing a 5\% biomass loss would be about 2.5-3.5 times higher than for deciduous oaks. Efforts for developing critical levels for Mediterranean evergreen species are ongoing, and the data presented here can contribute towards this goal. However, sound CLe should be based on as much experimental data as possible, as differences in ozone sensitivity within provenances or subspecies of this oak may be high (compare with Ribas et al., 2005b). Any risk assessment of Mediterranean forests should also take into consideration the above-described diversity of responses among species; i.e., the CLe for evergreens, when developed, should not be applied by default to the whole Mediterranean area, as Mediterranean vegetation also includes forests of relatively sensitive species such as $Q$. pyrenaica.

\section{Acknowledgements}

We thank both the Ministerio de Medio Ambiente y Medio Rural y Maritimo (in collaboration with ICP-Forests), and the Conselleria de Medi Ambient, Aigua i Habitatge and Interreg III (ForMedOzone and VegetPollOzone projects) for supporting the OTC activity. Instituto Universitario CEAM-UMH is also supported by Generalitat Valenciana and Fundación Bancaja, benefiting from CONSOLIDERINGENIO 2010 (GRACCIE) and Prometeo (Generalitat Valenciana) Programs. Filippo Bussotti and two anonymous referees are thanked for their useful comments. Carmen Martín is also thanked for taking care of the plants.

\section{References}

Alonso, R., Elvira, S., Castillo, F.J., Gimeno, B.S., 2001. Interactive effects of ozone and drought stress on pigments and activities of antioxidative enzymes in Pinus halepensis. Plant, Cell and Environment 24, 905-916.

Andersen, C.P., 2003. Source-sink balance and carbon allocation below ground in plants exposed to ozone. New Phytologist 157, 213-228.

Bennet, J.P., Rassat, P., Berbang, P., Karnosky, D.F., 1992. Relationships between leaf anatomy and ozone sensitivity of Fraxinus pennsylvanica Marsh. and Prunus serotina Ehrh. Environmental \& Experimental Botany 32, 33-41.

Broadmeadow, M.S.J., Heath, J., Randle, T.J., 1999. Environmental limitations to $\mathrm{O}_{3}$ uptake - some key results from young trees growing at elevated $\mathrm{CO}_{2}$ concentrations. Water, Air \& Soil Pollution 116, 299-310.

Broadmeadow, M.S.J., Jackson, S.B., 2000. Growth responses of Quercus petraeaFraxinus excelsior and Pinus sylvestris to elevated carbon dioxide, ozone and water supplyFraxinus excelsior and Pinus sylvestris to elevated carbon dioxide, ozone and water supply Fraxinus excelsior and Pinus sylvestris to elevated carbon dioxide, ozone and water supply. New Phytologist 146, 437-451.

Bussotti, F., 2008. Functional leaf traits, plant communities and acclimation processes in relation to oxidative stress in trees: a critical overview. Global Change Biology 14, 2727-2739.

Bussotti, F., Desotgiu, R., Cascio, C., Strasser, R.J., Gerosa, G., Marzuoli, R., 2007 Photosynthesis responses to ozone in young trees of three species with different sensitivities, in a two-year open-top chamber experiment (Curno Italy). Physiologia Plantarum 130, 122-135.

Bytnerowicz, A., Omasa, K., Paoletti, E., 2007. Integrated effects of air pollution and climate change on forests: a northern hemisphere perspective. Environmental Pollution 147, 438-445.

Calatayud, V., Cerveró, J., Sanz, M.J., 2007. Foliar, physiologial and growth responses of four maple species exposed to ozone. Water, Air \& Soil Pollution 185, 239-254.

Calatayud, V., Marco, F., Cerveró, J., Sánchez-Peña, G., Sanz, M.J., 2010. Contrasting ozone sensitivity of related evergreen and deciduous shrubs. Environmental Pollution 158, 3580-3587.

Cascio, C.h., Schaub, M., Novak, K., Desotgiu, R., Bussotti, F., Strasser, R.J., 2010. Foliar responses to ozone of Fagus sylvatica L. seedlings grown in shaded and in full sunlight conditions. Environmental and Experimental Botany 68, 188-197.

Chappelka, A.H., Samuelson, L.J., 1998. Ambient ozone effects on forest trees of the eastern United States: a review. New Phytologist 139, 91-108.

Elvira, S., Bermejo, V., Manrique, E., Gimeno, B.S., 2004. On the response of two populations of Quercus coccifera to ozone and its relationship with ozone uptake. Atmospheric Environment 38, 2305-2311.

Fredericksen, T.S., Kolb, T.E., Skelly, J.M., Steiner, K.C., Joyce, B.J., Savage, J.E., 1996 Light environment alters ozone uptake per net photosynthetic rate in black cherry trees. Tree Physiology 16, 485-490.

Gallego, H.A., Rico, M., Moreno, G., Santa-Regina, I., 1994. Leaf water potential and stomatal conductance in Quercus pyrenaica Willd. forests: vertical gradients and response to environmental factors. Tree Physiology 14, 1039-1047.

Gerosa, G., Vitale, M., Finco, A., Manes, F., Ballarin-Denti, A., Cieslik, S., 2005. Ozone uptake by an evergreen Mediterranean forest (Quercus ilex) in Italy. Part I. micrometeorological flux measurements and flux partitioning. Atmospheric Environment 39, 3255-3266.

Gerosa, G., Marzuoli, R., Desotgiu, R., Bussotti, F., Ballarin-Denti, A., 2008. Visible leaf injury in young trees of Fagus sylvatica L. and Quercus robur L. in relation to ozone uptake and ozone exposure. an open-top chambers experiment in South Alpine environmental conditions. Environmental Pollution 152, 274-284.

Harmens, H., Mills, G., Hayes, F., Norris, D., the participants of the ICP Vegetation, 2010. Air Pollution and Vegetation. ICP-vegetation Annual Report 2009/2010. Centre for Ecology and Hydrology, Bangor, UK.

Inclán, R., Ribas, A., Peñuelas, J., Gimeno, B.S., 1999. The relative sensitivity of different mediterranean plant species to ozone exposure. Water, Air \& Soil Pollution 116, 273-277.

Karlsson, P.E., Uddling, J., Braun, S., Broadmeadow, M., Elvira, S., Gimeno, B.S., Le Thiec, D., Oksanen, E., Vandermeiren, K., Wilkinson, M., Emberson, L., 2004 New critical levels for ozone effects on young trees based on AOT40 and simulated cumulative leaf uptake of ozone. Atmospheric Environment 38 2283-2294. 
Karlsson, P.E., Braun, S., Broadmeadow, M., Elvira, S., Emberson, L., Gimeno, B.S., Le Thiec, D., Novak, K., Oksanen, E., Schaub, M., Uddling, J., Wilkinson, M., 2007. Risk assessments for forest trees: the performance of the ozone flux versus the AOT concepts. Environmental Pollution 146, 608-616.

Krupa, S., McGrath, M.T., Andersen, C.P., Booker, F., Burkey, K.O., Chappelka, A.H., Chevone, B.I., Pell, E.J., Zilinskas, B.A., 2000. Ambient ozone and plant health. Plant Disease 85, 4-12

López-González, G., 2001. Los árboles y arbustos de la Península Ibérica e Islas Baleares (especies silvestres y las principales cultivadas). Ediciones Mundi Prensa, Madrid.

Lyons, T., Plöch, M., Turcsány, E., Barnes, J., 2000. Extracellular antioxidants: a protective screen against ozone?. In: Environmental Pollution and Plant Responses. Lewis Publishers, Boca Raton, London, New York, Washington, pp. 183-201.

Manes, F., Vitale, M., Donato, E., Paoletti, E., 1998. $\mathrm{O}_{3}$ and $\mathrm{O}_{3}+\mathrm{CO}_{2}$ effects on a mediterranean evergreen broadleaf tree, holm oak (Quercus ilex L.). Chemosphere 36, 801-806.

Manes, F., Vitale, M., Fabi, A.M., De Santis, F., Zona, D., 2007. Estimates of potentia ozone stomatal uptake in mature trees of Quercus ilex in a Mediterranean climate. Environmental and Experimental Botany 59, 235-241.

Matyssek, R., Bytnerowicz, A., Karlsson, P.E., Paoletti, E., Sanz, M., Schaub, M., Wieser, G., 2007. Promoting the $\mathrm{O}_{3}$ flux concept for European forest trees. Environmental Pollution 146, 587-607.

Mediavilla, S., Escudero, A., 2003. Stomatal responses to drought at a Mediterranean site: a comparative study of co-occurring woody species differing in leaf longevity. Tree Physiology 23, 987-996.

Mikkelsen, T.N., 1995. Physiological responses of Fagus sylvatica L. exposed to low levels of ozone in open-top chambers. Trees 9, 355-361.

Nali, C., Paoletti, E., Marabottini, R., Della Roca, G., Lorenzini, G., Paolacci, A.R Ciaffi, M., Badiani, M., 2004. Ecophysiological and biochemical strategies of response to ozone in Mediterranean evergreen broadleaf species. Atmospheric Environment 38, 2247-2257.

Novak, K., Cherubini, P., Saurer, M., Fuhrer, J., Skelly, J.M., Kräuchi, N., Schaub, M. 2007. Ozone air pollution effects on tree-ring growth, $\delta^{13} \mathrm{C}$, visible foliar injury and leaf gas exchange in three ozone-sensitive woody plant species. Tree Physiology 27, 941-949.

Official Journal of the European Union, 11 June 2008. Directive 2008/50 CE of the European Parliament and Council of 21 May 2008 on ambient air quality and cleaner air for Europe, L152/1-L152/44.

Pääkkönen, E., Paasisalo, S., Holopainen, T., Karenlampi, L., 1993. Growth and stomatal responses of birch (Betula pendula Roth) clones to ozone in open-air and chamber fumigations. New Phytologist 125, 615-623.

Pääkkönen, E., Holopainen, T., Karenlampi, L., 1995a. Ageing-related anatomical and ultrastructural changes in leaves of birch (Betula pendula Roth) clones as affected by low ozone exposure. Annals of Botany 75, 285-294.
Pääkkönen, E., Metsarinne, S., Holopainen, T., Karenlampi, L., 1995b. The ozone sensitivity of birch (Betula pendula) in relation to the developmental stage of leaves. New Phytologist 132, 145-154.

Pääkkönen, E., Holopainen, T., Karenlampi, L., 1997. Variation in ozone sensitivity among clones of Betula pendula and Betula pubescens. Environmental Pollution 95, 37-44.

Paoletti, E., 2005. Ozone slows stomatal response to light and leaf wounding in a Mediterranean evergreen broadleaf, Arbutus unedo. Environmental Pollution $134,439-445$

Paoletti, E., 2006. Impact of ozone on Mediterranean forests: a review. Environmental Pollution 144, 463-474.

Paoletti, E., Gellini, R., 1993. Stomatal density variation in beech and holm oak leaves collected over the last 200 years. Acta Oecologica 14, 173-178.

Reich, P.B., 1987. Quantifying plant response to ozone: a unifying theory. Tree Physiology 3, 63-91.

Reichenauer, T.G., Bolhàr-Nordenkampf, H.R., 1999. Mechanisms of impairment of the photosynthetic apparatus in intact leaves by ozone. Zeitschrift für Naturforschung 54c, 824-829.

Ribas, A., Peñuelas, J., Elvira, S., Gimeno, B.S., 2005a. Contrasting effects of ozone under different water supplies in two Mediterranean tree species. Atmospheric Environment 39, 685-693.

Ribas, A., Peñuelas, J., Elvira, S., Gimeno, B.S., 2005b. Ozone exposure induces the activation of leaf senescence-related processes and morphological and growth changes in seedling of Mediterranean tree species. Environmental Pollution $134,291-300$

Sanz, M.J., Calatayud, V. Ozone injury in European forest species. http://www. ozoneinjury.org/ (accessed March 2010).

UNECE, ICP Modelling and Mapping, 2004. Chapter 3, mapping critical levels for vegetation. Mapping manual 2004. In: Manual on Methodologies and Criteria for Modelling and Mapping Critical Loads and Levels and Air Pollution Effects, Risks and Trends. UNECE Convention on Long-Range Transboundary Air Pollution, pp. III.1-III.52. http://icpvegetation.ceh.ac.uk.

U.S. EPA, 2006. Air Quality Criteria for Ozone and Related Photochemical Oxidants (2006 Final). U.S. Environmental Protection Agency, Washington, DC. EPA/600/ R-05/004aF-cF.

Wei, C., Skelly, J.M., Pennypacker, S.P., Ferdinand, J.A., Savage, J.E., Stevenson, R.E., Davis, D.D., 2004a. Responses of hybrid poplar clones and red maple seedlings to ambient $\mathrm{O}_{3}$ under different light within a mixed hardwood forest. Environmental Pollution 130, 199-214.

Wei, C., Skelly, J.M., Pennypacker, S.P., Ferdinand, J.A., Savage, J.E., Stevenson, R.E., Davis, D.D., 2004b. Influence of light fleck and low light on foliar injury and physiological response on two hybrid poplar clones to ozone. Environmental Pollution 130, 215-227. 